\title{
INFRARED SPECTROSCOPY OF THE SURFACE OF THERMALLY-MODIFIED TEAK JUVENILE WOOD
}

\author{
Juliana de Oliveira Lopes ${ }^{1}$, Rosilei Aparecida Garcia ${ }^{2,,}$, Natália Dias de Souza ${ }^{2}$
}

\begin{abstract}
During the thermal modification of the wood there is a decreasing gradient of temperature from the surface to its interior, therefore, the most severe chemical modifications occur on the surface. These chemical modifications directly affect the quality and durability of adhesives and coating. Therefore, this study investigated the chemical modification of the surface of thermally-modified teak juvenile wood. Heartwood and sapwood samples were treated at 180 and $200^{\circ} \mathrm{C}$. Chemical analyses were performed by Fourier transform infrared spectroscopy (FTIR) in reflectance mode with a microscope. Spectra showed an increase in cellulose crystallinity and a decrease in relative contents of hydroxyl groups, lignin and extractives - especially quinones, waxes and oils - following thermal modification. Extractive content of the heartwood was relatively higher than that of sapwood. Heartwood was more susceptible to thermal degradation than sapwood.
\end{abstract}

Keywords: Cellulose crystallinity, chemical modification, heat treatment, quinone derivatives, Tectona grandis.

\section{INTRODUCTION}

Thermal modification provides desirable properties to wood such as increased resistance to fungal degradation (Weiland and Guyonnet 2003), greater dimensional stability (Syrjäne 2001) and change on the original colour (Lopes et al. 2014). It is an alternative method to the use of chemical preservatives in which wood is heated to temperatures ranging from 160 to $250^{\circ} \mathrm{C}$, usually near to $200^{\circ} \mathrm{C}$, for variable processing time depending on the intrinsic characteristics of the wood species and the desired properties for the final product. Although the treatment causes physical and chemical modifications in the cellular structure of the wood, the chemical modifications are the most important because of their impact to the properties of the thermally-modified material. For example, on thermallymodified wood occurs conversion of hydroxyl $(\mathrm{OH})$ groups in cross-ether bonds between the polymers of the cell wall; extractive volatilization and migration to the surfaces (Christiansen 1994); reaction of depolymerization of hemicelluloses; degradation of the amorphous region of cellulose; increasing in cellulose crystallinity with a decrease of the free $\mathrm{OH}$ groups (Boonstra and Tjeerdsma 2006); and condensation and crosslinking between lignin and the products resulting from thermal degradation (Tjeerdsma and Militz 2005) which reduce the hygroscopicity. Hence, during thermal modification of wood are initiated various hydrolysis, oxidation and mass transfer reactions resulting in a modified structure (Popescu and Popescu 2013). The reduction in free OH groups has a positive impact on the

\footnotetext{
${ }^{1}$ Doctor student. Departamento de Produtos Florestais Departamento de Produtos Florestais, Instituto de Florestas, Universidade Federal Rural do Rio de Janeiro (UFRRJ), Seropédica, Rio de Janeiro. Brazil.

${ }^{2}$ Professor. Departamento de Produtos Florestais Departamento de Produtos Florestais, Instituto de Florestas, Universidade Federal Rural do Rio de Janeiro (UFRRJ), Seropédica, Rio de Janeiro. Brazil.

•Corresponding author: rosileigar@ufrrj.br

Received: 26.09.2017 Accepted: 17.07.2018
} 
wood resistance to water penetration, resulting in a more hydrophobic and dimensionally stable material (Weiland and Guyonnet 2003, Rousset et al. 2004, Wikberg and Maunu 2004). Thermal modification can also degrade the anatomical structure of wood (Awoyemi and Jones 2011) and increase its porosity (Nunes et al. 2016). Awoyemi and Jones (2011) observed a degradation in the bordered pits of the tracheids of Thuja plicata wood following thermal modification. Nunes et al. (2016) observed a higher adhesive penetration in the thermally-modified Eucallyptus pellita and Corymbia citriodora woods compared to unmodified wood due to increased porosity. All these modifications can also affect the quality and durability of adhesives and coatings applied to wood surfaces.

The teak wood has a high commercial value due to the excellent physical and mechanical properties. However, teak wood from Brazilian plantations has peculiar characteristics such as high proportion of juvenile wood (short cutting cycle - 25 years) (Shimizu et al. 2007) and higher proportion of sapwood, which has physical, chemical and aesthetic characteristics (color and design) different from those of heartwood. The composition and content of extractives are different between heartwood and sapwood. In teak wood are found various quinone derivatives, some present in heartwood and sapwood such as 2-hydroxymethyl; and other exclusively in heartwood such as anthraquinone, 1,4-naphthoquinone, anthraquinone-2-carboxylic acid and lapachol (Niamké et al. 2011). Teak sapwood has high concentration of starch, sucrose, glucose and fructose and low concentrations of $\mathrm{H} 1$ (hydroxycinnamic acid derivative) and tectoquinone (Niamké et al. 2011). The largest natural durability of the heartwood compared to that of sapwood could be explained by the higher concentration of 2-hydroxymethyl anthraquinone, tectoquinone (Moreira et al. 2006, Niamké et al. 2011, Nidavani and Mahalaksmi 2014) and lapachol (Nidavani and Mahalaksmi 2014), which have phenolic nature. The lapachol is one of the most studied naphthoquinones in the fields of chemistry and pharmacology due to its therapeutic applications such as anti-inflammatory, antimalarial, antiseptic, antitumor, antiviral, antibactericidal and fungicidal (Hussain et al. 2007). The teak wood also presents caoutchouc in the cell wall and lumen, which are responsible for the hydrophobicity and antioxidant properties of the wood (Yamamoto et al. 1998). Heartwood contains higher caoutchouc concentration than sapwood, giving it lower permeability (Yamamoto et al. 1998). The amount of extractives also depends of the tree age. Haupt et al. (2003) found higher extractives amount in teak heartwood from fast-grown plantation trees (29 years-old) than from natural stands (100 years-old).

Thermal modification could provide greater durability and dimensional stability to the teak sapwood besides standardizes the color of wood pieces containing heartwood and sapwood (Lopes et al. 2014). The chemical modifications of lignocellulosic materials following thermal modification have been evaluated by several spectroscopic methods among them the Fourier transformed infrared (FTIR) spectroscopy stands out for providing quickly and effectively information on the composition of the functional groups (Li et al. 2015). However, the FTIR analysis of thermally-modified wood are usually held for sapwood (Fabiyi and Ogunleye 2015), whose composition is less complex than heartwood. Furthermore, several studies evaluate the chemical modification of thermally-modified wood by FTIR spectroscopy (Li et al. 2015) potassium bromide pellet (KBr) method, which does not allow assessing the condition of the wood surface. During the thermal modification have a decreasing gradient of temperature from surfaces to the interior of the wood, therefore the surface modifications are more severe than the inner part, emphasizing the importance of evaluating the surface condition using FTIR spectroscopy in the reflectance mode. In this context, this study investigated the chemical modification of the surface of teak juvenile wood following thermal modification by FTIR spectroscopy in the reflectance mode using a microscope.

\section{MATERIAL AND METHODS}

\section{Material and thermal modification}

Teak (Tectona grandis L. f.) wood samples with nominal dimensions of $150 \mathrm{~mm} \times 75 \mathrm{~mm} \times 20 \mathrm{~mm}$ were obtained from six trees of 12 years old. The material was separated in heartwood and sapwood, air dried and conditioned at $20^{\circ} \mathrm{C}$ and $65 \%$ relative humidity (RH) in a climate chamber until constant weight. 
The thermal modification was carried out in an electric laboratorial muffle furnace from Linn Elektro Therm, with dimensions of $600 \mathrm{~mm}$ x $600 \mathrm{~mm}$ x $700 \mathrm{~mm}$ equipped with a system of temperature and time control. The treatment was conducted in four steps at two different temperatures: 180 and $200^{\circ} \mathrm{C}$. The four steps were: (1) heating up to $100^{\circ} \mathrm{C}$ for $2 \mathrm{~h}$; (2) increase of temperature from $100^{\circ} \mathrm{C}$ to final temperature $\left(180\right.$ or $\left.200^{\circ} \mathrm{C}\right)$ for $30 \mathrm{~min}$; (3) treatment time in the selected temperature for $2 \mathrm{~h}$ and $30 \mathrm{~min}$; and (4) cooling for approximately $1 \mathrm{~h}$. The initial moisture content of the samples was approximately $8-10 \%$ (based on the oven-dry of the wood). After thermal modification, samples were conditioned at $20^{\circ} \mathrm{C}$ and $65 \% \mathrm{RH}$ until constant weight.

\section{FTIR spectroscopy}

The chemical structure of the surfaces of unmodified and thermally-modified heartwood and sapwood was analyzed by FTIR spectroscopy in the reflectance mode using a microscope coupled to a VARIAN 640-IR spectrometer. Infrared measurements were performed at a resolution of $4 \mathrm{~cm}^{-1}$, 128 scans and spectral range between $4000-400 \mathrm{~cm}^{-1}$. The FTIR spectra were obtained from the wood surfaces without prior preparation, baseline-corrected and normalized afterwards.

\section{RESULTS AND DISCUSSION}

The FTIR spectra of the surface of unmodified and thermally-modified heartwood and sapwood are shown in Figure 1 and Figure 2. Table 1 summarizes the FTIR band assignments of the unmodified and thermally-modified heartwood and sapwood. The effect of thermal modification on teak heartwood and sapwood surfaces was evaluated by the peaks corresponding to the lignin, polysaccharides (cellulose and hemicelluloses) and extractives, specifically quinones and oils.

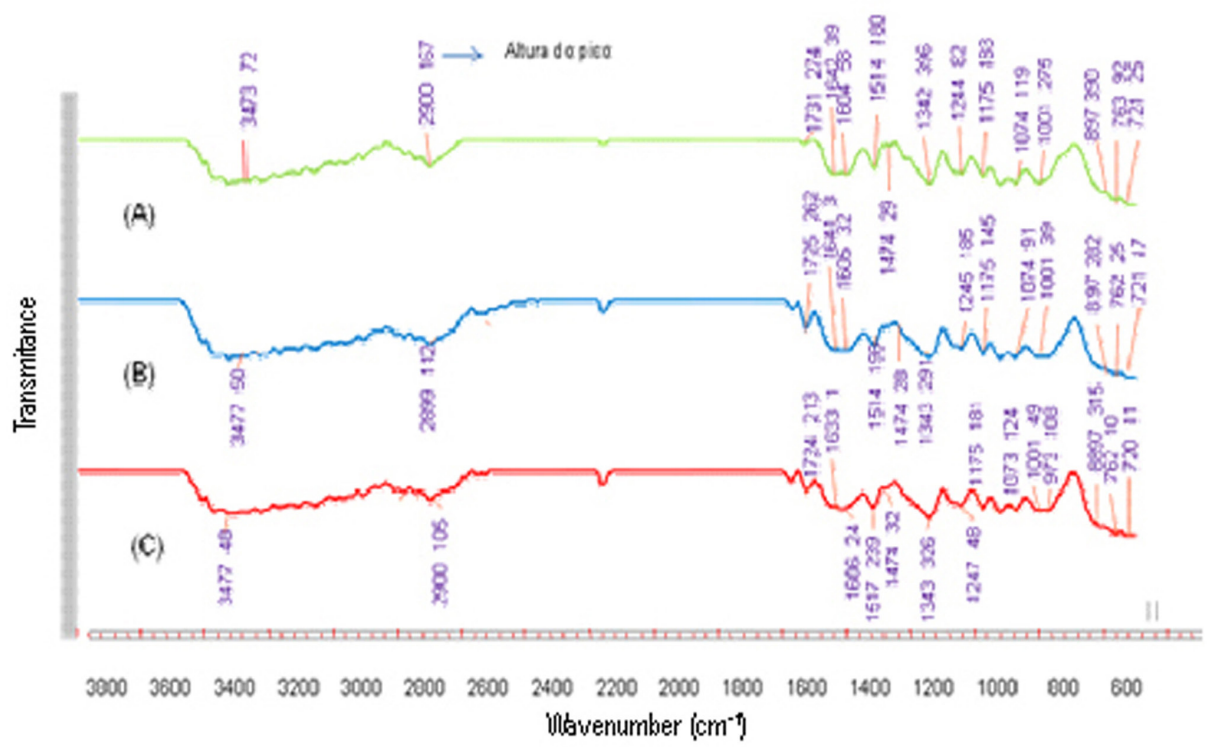

Figure 1. FTIR spectra of teak heartwood. A: unmodified wood. B and C: thermally-modified woods at 180 and $200^{\circ} \mathrm{C}$, respectively. 


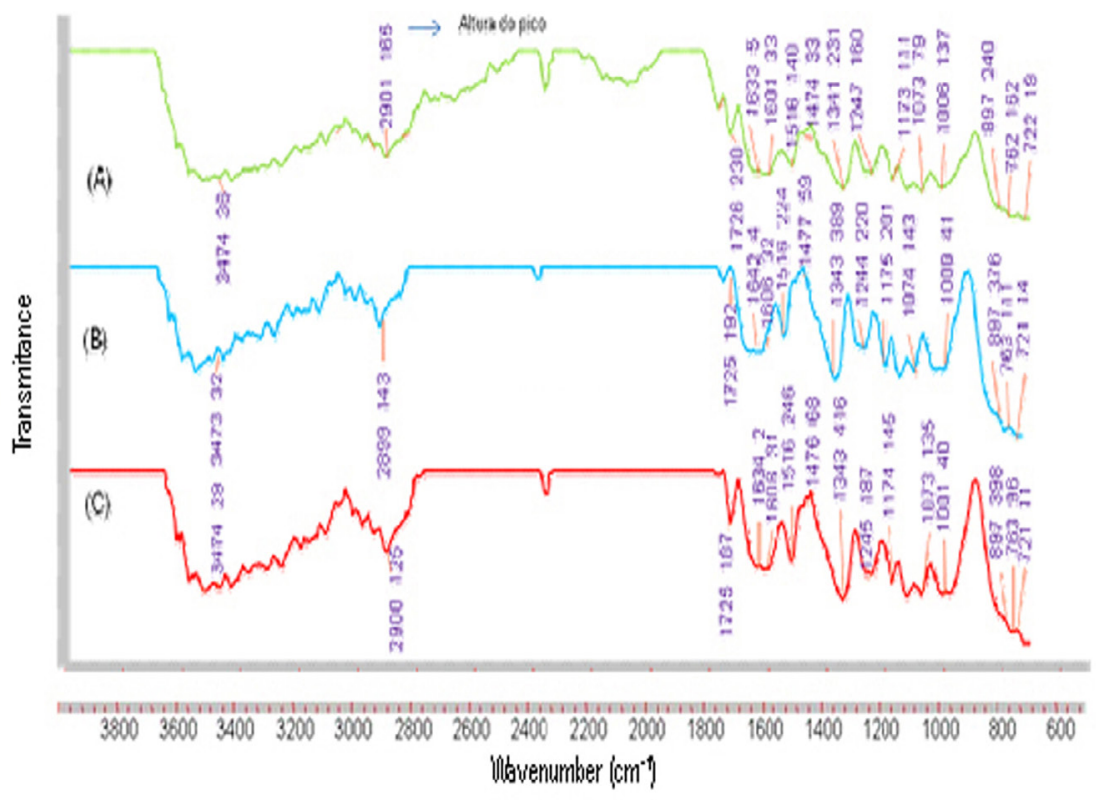

Figure 2. FTIR spectra of teak sapwood. A: unmodified wood. B and C: thermally-modified woods at 180 and $200^{\circ} \mathrm{C}$, respectively.

Table 1. Summary of FTIR spectroscopy band assignments of unmodified and thermally-modified teak heartwood and sapwood.

\begin{tabular}{|c|c|c|}
\hline$\underset{\left(\mathrm{cm}^{-1}\right)}{\text { Wavenumber }}$ & Band assignment & Polymer \\
\hline$\approx 3470$ & O-H stretching & Polymers $^{[1]}$ \\
\hline$\approx 2900, \approx 2943$ & $\mathrm{CH}-\mathrm{sp}^{3}$ stretching & Polymers $^{[2]}$ \\
\hline$\approx 1725$ & $\mathrm{C}=\mathrm{O}$ stretching of carbonyl, carboxyl and acetyl groups; and of xylans & $\begin{array}{l}\text { Oils }^{[3]} \text {; cellulose and } \\
\text { hemicelluloses } \\
\text { hi-5] }^{[-5}\end{array}$ \\
\hline$\approx 1640$ & Conjugation of $\mathrm{C}=\mathrm{O}$ with two aromatic rings & Quinones $^{[3]}$ \\
\hline$\approx 1514$ & Aromatic skeletal vibration $(\mathrm{C}=\mathrm{C})$ of lignin, guaiacyl $>$ syringyl & $\operatorname{Lignin}^{[1]}$ \\
\hline$\approx 1474$ & $\begin{array}{l}\mathrm{C}-\mathrm{H} \text { deformation in lignin and carbohydrates; } \\
\mathrm{CH}_{2} \text { symmetric angular deformation and } \mathrm{CH}_{3} \text { angular asymmetric angular } \\
\text { deformation }\end{array}$ & $\begin{array}{l}\text { Lignini }^{[1]} \\
\text { Oils and waxes }\end{array}$ \\
\hline$\approx 1342$ & $\mathrm{C}-\mathrm{H}_{2}$ deformation vibration; $\mathrm{CH}_{3}$ symmetric deformation & $\begin{array}{l}\text { Cellulose and } \\
\text { hemicelluloses }^{[1]} \text {; } \\
\text { oils }^{[3]}\end{array}$ \\
\hline$\approx 1245$ & $\mathrm{C}-\mathrm{C}, \mathrm{C}-\mathrm{O}$ and $\mathrm{C}=\mathrm{O}$ stretching; $\mathrm{G}$ condensed $>\mathrm{G}$ etherified; $\mathrm{C}-\mathrm{O}$ stretching & $\begin{array}{l}\operatorname{Lignin}^{[1]} \\
\text { oils }^{[3]}\end{array}$ \\
\hline$\approx 1175$ & C-O-C stretching; C-O stretching & $\begin{array}{l}\text { Cellulose and } \\
\text { hemicelluloses }{ }^{[6]} \text {; } \\
\text { oils }^{[3]}\end{array}$ \\
\hline$\approx 1074$ & $\begin{array}{l}\text { C-O stretching of secondary alcohol; C-O stretching of the ester methoxyl } \\
\text { group and B-O-4 links in lignin }\end{array}$ & $\begin{array}{l}\text { Cellulose and } \\
\text { hemicelluloses }^{[1]} \text {; } \\
\text { lignin }^{[7]}\end{array}$ \\
\hline$\approx 1000$ & $\mathrm{C}-\mathrm{O}$ stretching of primary alcohol & $\begin{array}{l}\text { Cellulose and } \\
\text { hemicelluloses }^{[1]}\end{array}$ \\
\hline$\approx 720, \approx 760$ & $\left(\mathrm{CH}_{2}\right) \mathrm{n}$ out-of-plane angular deformation, $\mathrm{n}>4$ & Oils and waxes ${ }^{[3]}$ \\
\hline
\end{tabular}

${ }^{[1]}$ Faix (1992). ${ }^{[2]}$ Faix (1991). ${ }^{[3]}$ Barbosa (2007). ${ }^{[4]}$ Fengel and Ludwig (1991). ${ }^{[5]}$ Lionetto et al. (2012). ${ }^{[6]}$ Pandey (1999). ${ }^{[7]}$ González-Pena and Hale (2011). 
The peak intensities (height) at $3470 \mathrm{~cm}^{-1}$ assigned to the $\mathrm{OH}$ groups decreased significantly to thermally-modified heartwood and sapwood (Figures 1 and 2). The heartwood and sapwood treated at $180^{\circ} \mathrm{C}$ had a decrease in the order of $31 \%$ and $11 \%$, respectively, whereas for the treatment at $200^{\circ} \mathrm{C}$ was around $33 \%$ and $19 \%$. Thus, the $\mathrm{OH}$ group decrease was more pronounced to heartwood in both temperatures. These decrease of the $\mathrm{OH}$ groups could be explained by its thermal degradation but also by different amount of water contained unmodified and thermally-modified heartwood and sapwood. The thermally-modified woods have lower equilibrium moisture content (EMC) compared to unmodified woods therefore a smaller amount of water while heartwood has a lower EMC than sapwood (Lopes 2018).

The hemicelluloses are largely responsible for moisture absorption, but the accessible cellulose, nanocrystalline cellulose, lignin and crystalline cellulose also play an important role (Mohanty et al. 2000). Therefore, the relative contents of the cellulose crystallinity, amorphous region of cellulose and lignin were calculated (Table 2). The relative cellulose crystallinity was estimated by the ratio between $1474 \mathrm{~cm}^{-1}$ and $897 \mathrm{~cm}^{-1}$ peak intensities assigned to the $\mathrm{C}-\mathrm{H}$ in lignin and $\mathrm{C}-\mathrm{H}_{1}$ deformation of cellulose glucose ring, respectively; and $1342 \mathrm{~cm}^{-1}$ and $2900 \mathrm{~cm}^{-1}$ peaks intensities assigned to $\mathrm{C}=\mathrm{O}$ stretching in carbonyls and $\mathrm{CH}-\mathrm{sp}^{3}$ stretching (Ates et al. 2009, Tuong and Li 2010). For the amorphous region of cellulose was used the $2900 \mathrm{~cm}^{-1}$ and $1074 \mathrm{~cm}^{-1}$ peak intensities assigned to the $\mathrm{CH}-\mathrm{sp}^{3}$ and $\mathrm{C}-\mathrm{O}$ stretching of secondary alcohol, respectively; and $2900 \mathrm{~cm}^{-1}$ and $3474 \mathrm{~cm}^{-1}$ peak intensities assigned to the $\mathrm{CH}-\mathrm{sp}^{3}$ and $\mathrm{O}-\mathrm{H}$ stretching (Fackler et al. 2011, Temiz et al. 2006).

Table 2. Relative values of cellulose crystallinity and amorphous regions, and lignin of unmodified and thermally-modified teak heartwood and sapwood.

\begin{tabular}{|c|c|c|c|c|c|c|}
\hline \multirow{3}{*}{ Wood } & \multirow{3}{*}{$\begin{array}{c}\text { Temperature } \\
\left({ }^{\circ} \mathrm{C}\right)\end{array}$} & \multirow{2}{*}{\multicolumn{2}{|c|}{$\begin{array}{l}\text { Cellulose crystallinity } \\
\mathrm{C}-\mathrm{H} / \mathrm{CH}_{2} \quad \mathrm{CH}_{2 /} \mathrm{C}-\mathrm{H}\end{array}$}} & \multicolumn{2}{|c|}{$\begin{array}{c}\text { Amorphous region of } \\
\text { cellulose }\end{array}$} & \multirow{3}{*}{$\begin{array}{l}\text { Lignin } \\
1514 / 897\end{array}$} \\
\hline & & & & $\mathrm{C}-\mathrm{H} / \mathrm{C}-\mathrm{O}-$ & C-H/O-H & \\
\hline & & $1474 / 897$ & $1342 / 2900$ & $2900 / 1074$ & $2900 / 3474$ & \\
\hline \multirow[t]{3}{*}{ Heartwood } & control & 0,074 & 2,33 & 1,40 & 2,31 & 0,46 \\
\hline & 180 & 0,099 & 2,51 & 1,23 & 2,24 & 0,67 \\
\hline & 200 & 0,1 & 3,00 & 0,84 & 2,18 & 0,75 \\
\hline \multirow[t]{3}{*}{ Sapwood } & control & 0,13 & 2,78 & 1,98 & 4,58 & 0,58 \\
\hline & 180 & 0,15 & 2,79 & 0,98 & 4,46 & 0,59 \\
\hline & 200 & 0,17 & 3,32 & 0,92 & 4,31 & 0,61 \\
\hline
\end{tabular}

The relative content of cellulose crystallinity of thermally-modified wood increased in comparison to unmodified wood (Table 2) which agrees with the results of other authors (Tuong and Li 2010). The cellulose crystallinity of thermally-modified heartwood increased $20.4 \%$ and $31.5 \%$ whereas in thermally-modified sapwood increased $7.65 \%$ and $9.65 \%$ for $180^{\circ} \mathrm{C}$ and $200^{\circ} \mathrm{C}$, respectively (Table 2). Therefore, the increase in crystallinity cellulose was more important to the highest temperature $\left(200^{\circ} \mathrm{C}\right)$ and to heartwood. This increasing in cellulose crystallinity following thermal modification has been reported by various authors for different wood species. Bhuyian et al. (2000) studied the effect of the thermal modification on the cellulose crystallites of different wood species and pure cellulose under oven-dried and high moisture conditions by X-ray diffractometer and observed a rearrangement of the cellulose molecules in the amorphous regions leading to crystallization. The cellulose crystallinity was almost twice higher in moisture condition than oven-dried condition to wood; but pure cellulose had almost the same crystallization under both conditions. Thus, according to these authors, other components of cell wall such as xylose and mannose not degraded during thermal modification are involved in the crystallinity increase. Li et al. (2015) studied the steam-heat treated teak wood by FTIR and second derivative IR (SD-IR) spectroscopy and observed an increase in the stretching vibration of glucose ring, probably due to cleavage and dehydration of amorphous carbohydrates and/or crystallization of the paracrystalline region of cellulose, which may cause the increase of the proportion of crystalline cellulose. 
The degradation of hemicelluloses and amorphous region following thermal modification contributes to an increase in the proportion of crystalline cellulose of wood (Hill 2006). Besides the degradation of $\mathrm{OH}$ groups, the increased cellulose crystallinity also could contribute to higher hydrophobicity of the thermally-modified wood. Tjeerdsma et al. (1998) found a reduction on water adsorption of thermallymodified wood and they attributed it to the increase in the relative proportion of cellulose crystallinity. Tsuchikawa and Siesler (2003) showed that solvent penetration in the amorphous region is faster than in crystalline regions.

The relative lignin content was calculated by the ratio between $1514 \mathrm{~cm}^{-1}$ and $897 \mathrm{~cm}^{-1}$ peak intensities assigned to aromatic ring vibration in lignin and $\mathrm{C}-\mathrm{H}_{1}$ deformation of cellulose glucose ring. A relative increase in lignin content was observed after thermal modification to both heartwood and sapwood (Table 2). These results agree with those of other authors (Poubel et al. 2013, de Moura et al. 2012, Batista et al. 2016, Yalcin and Sahin 2015). Thermally-modified heartwood had an increase of $45 \%$ and $63 \%$ in relative lignin content for $180^{\circ} \mathrm{C}$ and $200^{\circ} \mathrm{C}$, respectively, whereas in thermally-modified sapwood, they increased approximately $1.7 \%$ and $5.1 \%$. These results show that heartwood is more susceptible to degradation by heat than sapwood. According to Li et al. (2015), during thermal modification, some reactions such as condensation and degradation reactions in lignin as well as depolymerization reactions of carbohydrates can occur under catalysis of released acetic acid. These authors observed an increase at $1328 \mathrm{~cm}^{-1}$ peak intensity assigned to $\mathrm{C}_{1}-\mathrm{H}$ vibration in cellulose and $\mathrm{C}_{1}-\mathrm{O}$ vibration in syringyl derivatives-condensed structures in lignin, suggesting the condensation reactions in lignin structure of teak wood.

Teak heartwood has high natural durability due to tectoquinone, a bioactive compound against brown-rot fungi (Haupt et al. 2003); and high dimensional stability due to the waxes and oils formed and deposited in cell which are responsible by weak water absorption. Therefore, to evaluate the compounds modification following thermal modification, the extractive, quinone and oil contents of unmodified and thermally-modified heartwood/sapwood were determined (Table 3). The relative amount of extractives, quinones and oils were estimated by the ratio between their respectively peak intensity and the $1514 \mathrm{~cm}^{-1}$ wavenumber assigned to the aromatic skeletal vibration $(\mathrm{C}=\mathrm{C})$ in lignin (Sarkanen et al. 1967a, Sarkanen et al. 1967b, Sun et al. 2011, Gonçalves and Schuchardt 1999) which was chosen as reference due to relative constant intensity (Faix 1992).

Table 3. Relative contents of extractives, quinones and oils of the unmodified and thermally-modified teak heartwood and sapwood.

\begin{tabular}{|c|l|l|l|l|l|}
\hline \multirow{3}{*}{ Wood } & \multirow{2}{*}{$\begin{array}{c}\text { Temperature } \\
\left({ }^{\circ} \mathbf{C}\right)\end{array}$} & Extractives & Quinones & \multicolumn{1}{|c|}{ Oils } & $\begin{array}{c}\text { Oils and } \\
\text { waxes }\end{array}$ \\
\cline { 3 - 6 } & & $\mathbf{1 6 0 0 / 1 5 1 4}$ & $\mathbf{1 6 4 0 / 1 5 1 4}$ & $\mathbf{1 7 2 5 / 1 5 1 4}$ & $\mathbf{7 2 2 / 1 5 1 4}$ \\
\hline \multirow{3}{*}{ Heartwood } & control & 0,32 & 0,21 & 1,52 & 0,13 \\
\cline { 2 - 6 } & 180 & 0,16 & 0,015 & 1,37 & 0,089 \\
\cline { 2 - 6 } & 200 & 0,10 & 0,004 & 0,89 & 0,046 \\
\hline \multirow{3}{*}{ Sapwood } & control & 0,13 & 0,020 & 0,95 & 0,07 \\
\cline { 2 - 6 } & 180 & 0,08 & 0,010 & 0,51 & 0,03 \\
\cline { 2 - 6 } & 200 & 0,07 & 0,005 & 0,46 & 0,02 \\
\hline
\end{tabular}

The relative amount of extractives in unmodified heartwood was $60 \%$ higher than those of unmodified sapwood. After heating at $180^{\circ} \mathrm{C}$ and $200^{\circ} \mathrm{C}$, the relative amount of extractive shut down $50 \%$ and $31 \%$ in heartwood and $61.5 \%$ and $53.8 \%$ in sapwood, respectively. The quinone was more abundant in unmodified heartwood with a relative amount of $21 \%$, whereas unmodified sapwood had $2 \%$. The peak intensity at $1640 \mathrm{~cm}^{-1}$ assigned to conjugation of $\mathrm{C}=\mathrm{O}$ in quinones decreased with the temperature increase. A decrease was also observed on the peak intensity at $1600 \mathrm{~cm}^{-1}$ assigned to $\mathrm{C}=\mathrm{C}$ stretching of aromatic rings, signal used to evaluate the peak intensity of wood extractives. The 
peak intensities at $1730 \mathrm{~cm}^{-1}$ are assigned to $\mathrm{C}=\mathrm{O}$ stretching in oils and at $720 \mathrm{~cm}^{-1}$ and $760 \mathrm{~cm}^{-1}$ to $\mathrm{CH}_{2}$ deformation in oils and waxes. These peak intensities were higher in heartwood and decreased following thermal modification.

\section{CONCLUSIONS}

This study permitted to observe the chemical modifications of the surfaces of thermally-modified teak heartwood and sapwood by FTIR spectroscopy. The thermal modification causes a relative increase in the degree of cellulose crystallinity and consequent reduction of the amorphous region of cellulose; and also a relative increase in the lignin content.

The extractive content of the heartwood is higher than that of sapwood. The treatment reduced the quinone content, oils and waxes in the wood and this was enhanced with increasing temperature.

Heartwood surface is more susceptible to degradation by heat than that of sapwood.

\section{REFERENCES}

Ates, S.; Akyildiz, M.H.; Ozdemir, H. 2009. Effects of heat treatment on calabrian pine (Pinus brutia Ten.) wood. BioResources 4(3): 1032-1043.

Awoyemi, L.; Jones, I.P. 2011. Anatomical explanations for the changes in properties of western red cedar (Thuja plicata) wood during heat treatment. Wood Sci Technol 45:261-267.

Barbosa, L.C. DE A. 2007. Espectroscopia no infravermelho na caracterização de compostos orgânicos. UFV, Viçosa.

Batista, D.C.; De Muniz, G.I.B.; Oliveira, J.T.S.; Paes, J.B.; Nisgoski, S. 2016. Effect of the Brazilian thermal modification process on the chemical composition of Eucalyptus grandis juvenile wood - part 1: cell wall polymers and extractives contents. Maderas-Cienc Tecnol 18(2):273-284.

Bhuiyan, T.R.; Hirai, N.; Sobue, N. 2000. Changes of crystallinity in wood cellulose by heat treatment under dried and moist conditions. $J$ Wood Sci 46:431-436.

Boonstra, M.J.; Tjeerdsma, B. 2006. Chemical analysis of heat treated softwoods. Holz als Rohund Werkstoff 64(3): 204-211.

Christiansen, A.W. 1994. Effect of overdrying of yellow-poplar veneer on physical properties and bonding. Holz als Roh- und Werkstoff 52:139-149.

de Moura, L.F.; Brito, J.O.; Da Silva, F.G. 2012. Effect of thermal treatment on the chemical characteristics of wood from Eucalyptus grandis W. Hill ex Maiden under different atmospheric conditions. Cerne 18(3):449-455.

Fabiyi, J.S.; Ogunleye, B.M. 2015. Mid-Infrared spectroscopy and dynamic mechanical analysis of heat-treated obeche (Triplochiton scleroxulon) wood. Maderas-Cienc Tecnol 17(1):5-16.

Fackler, K.; Stevanic, J.S.; Ters, T.; Hinterstoisser, B.; Schwanninger, M.; Salmén, L. 2011. FTIR imaging microscopy to localize and characterize simultaneous and selective white-rot decay 
within spruce wood cells. Holzforschung 65(3):411-420.

Faix, O. 1991. Classification of lignins from different botanical origins by FT-IR spectroscopy. Holzforschung 45: 21-27.

Faix, O. 1992. Fourier transform infrared spectroscopy. In: LIN, S.Y.; DENCE, C.W. (ed.) Methods in lignin chemistry. Springer-Verlag, Germany.

Fengel, D.; Ludwig, M. 1991. Possibilities and limits of FTIR spectroscopy characterization of the cellulose. Papier 45(2): 45-51.

Gonçalves, A.; Schuchardt, U. 1999. Oxidation of organosolv lignins in acetic acid: Influence of oxygen pressure. Applied Biochemistry and Biotechnology 77:127-132.

González-Pena, M.M.; Hale, M.D.C. 2011. Rapid assessment of physical properties and chemical composition of thermally modified wood by mid-infrared spectroscopy. Wood Sci Technol 45: 83-102.

Haupt, M.; Leithoff, D.; Meier, D.; Puls, J.; Richter, H.G.; Faix, O. 2003. Heartwood extractives and natural durability of plantation grown teakwood (Tectona grandis L.): a case study. Holz als Rohund Werkstoff 61(6):473-474.

Hill, C.A.S. 2006. Wood modification: Chemical, thermal and other processes. John Wiley \& Sons, Ltd., England.

Hussain, H.; Krohn, K.; Ahmad, V.U.; Miana, G.A.; Green, I.R. 2007. Lapachol: an overview. Arkivoc 145-171.

Li, M.Y.; Cheng, S.C.; Li, D.; Wang, S.N.; Huang, A.M.; Sun, S.Q. 2015. Structural characterization of steam-heat treated Tectona grandis wood analyzed by FT-IR and 2D-IR correlation spectroscopy. Chinese Chemical Letters 26:221-225.

Lionetto, F.; Sole, R.D.; Cannoletta, D.; Vasapollo, G.; Maffezzoli, A. 2012. Monitoring wood degradation during weathering by cellulose crystallinity. Materials 5(10):1910-1922.

Lopes, J.O. 2018. Physical-chemical characterization and surface wettability of the thermallymodified teak juvenile wood. Doctor Thesis, Universidade Federal Rural do Rio de Janeiro, Seropédica, Brazil

Lopes, J.O.; Garcia, R.A.; Nascimento, A.M.; Latorraca, J.V.F. 2014. Color uniformization of the young teak wood by heat treatment. Revista Arvore 38(3):561-568.

Mohanty, A.K.; Misra, M.; Hinrichsen, G. 2000. Biofibres, biodegradable polymers and biocomposites: An overview. Macromolecular Materials and Engineering 276/277(1):1-24.

Moreira, R.Y.O.; Arruda, M.S.P.; Arruda, A.C.; Santos, L.S.; Müller, A.H.; Guilhon, G.M.S.P.; Santos, A.S.; Terezo, E. 2006. Antraquinonas e naftoquinonas do caule de um espécime de reflorestamento de Tectona grandis (Vernenaceae). Revista Brasileira de Farmacognosia 16(3):392396.

Niamké, F.B.; Amusant, N.; Charpentier, J.-P.; Chaix, G.; Baissac, Y.; Boutahar, N.; Adima, A.A.; Kati-Coulibaly, S.; Jay-Allemand, C. 2011. Relationships between biochemical attributes (non-structural carbohydrates and phenolics) and natural durability against fungi in dry teak wood (Tectona grandis L. f.). Annals of Forest Science 68:201-211.

Nidavani, R.B.; Mhalaksmi, A.M. 2014. Teak (Tectona grandis Linn.): renowned timber plant with potential medicinal values. International Journal of Pharmacy and Pharmaceutical Sciences $6(1): 48-54$. 
Nunes, C.S.; Do Nascimento, A.M.; Garcia, R.A.; Lelis, R.C.C. 2016. Adhesion quality of the heat-treated Corymbia citriodora and Eucallyptus pellita woods. Scientia Forestalis 44(109):41-56.

Pandey, K.K. 1999. A study of chemical structure of soft and hardwood polymers by FTIR spectroscopy. Journal of Applied Polymer Science 71: 1969-1975.

Popescu, C.M.; Popescu, M.C. 2013. A near infrared spectroscopic study of the structural modifications of lime (Tilia cordata Mill.) wood during hydro-thermal treatment. Spectrochimica Acta Part A: Molecular and Biomolecular Spectroscopy 115:227- 233.

Poubel, D.S.; Garcia, R.A.; Santos, W.A.; Oliveira, G.L.; Abreu, H.S. 2013. Effect of the heat treatment on physical and chemical properties of Pinus caribaea wood. Cerne 19(3):391-398.

Rousset, P.; Perré, P.; Girard, P. 2004. Modification of mass transfer properties in poplar wood (P. robusta) by thermal treatment at high temperature. Holz als Roh- und Werkstoff 62(2):113-119.

Sarkanen, K.V.; Chang, H.M.; Ericsson, B. 1967a. Species variation in lignins. I. Infrared spectra of guaiacyl and syringyl models. Tappi Journal 50:572-575.

Sarkanen, K.V.; Chang, H.M.; Allan, G.G. 1967b. Species variation in lignins. II. Conifer lignins. Tappi Journal 50: 583-587.

Shimizu, J.Y.; Klein, H.; Oliveira, J.R.V. De. 2007. Diagnóstico das plantações florestais em Mato Grosso. Central de Texto, Cuiabá, MT.

Sun, S.Q.; Zhou, Q.; Chen, J.B. 2011. Infrared Spectroscopy for Complex Mixtures -Applications in Food and Traditional Chinese Medicine. Chemical Industry Press, Beijing.

Syrjänen, T. 2001. Production and classification of heat treated wood in Finland. In: RAPP, A. O. Review on heat treatments of wood. In: Special Seminar: Environmental Optimization of Wood Protection, 2001. Antibes, France. Proceedings... COST ACTION E 22, Antibes, France.

Temiz, A.; Terziev, N.; Jacobsen, B.; Eikenes, M. 2006. Weathering, water absorption and durability of silicon, acetylated and heat-treated wood. Journal of Applied Polymer Science 102:45064513.

Tjeerdsma, B.F.; Boonstra, M.; Pizzi, A.; Tekely, P.; Militiz, H. 1998. Characterization of thermally modified wood: molecular reasons for wood performance improvement. Holz als Roh-und Werkstoff 56(3):149-153.

Tjeerdsma, B.F.; Militz, H. 2005. Chemical changes in hydrothermal treated wood: FTIR analysis of combined hydrothermal and dry heat-treated wood. Holz als Roh- und Werkstoff 63(2):102-111.

Tsuchikawa, S.; Siesler, H.W. 2003. Near-infrared spectroscopic monitoring of the diffusion process of deuterium-labeled molecules in wood. Part II: Hardwood. Applied Spectroscopy 57(6):675681.

Tuong, V.M.; Li, J. 2010. Effect of heat treatment on the change in color and dimensional stability of Acacia hybrid wood. BioResources 5(2):1257-1267.

Weiland, J.J.; Guyonnet, R. 2003. Study of chemical modifications and fungi degradation of thermally modified wood using DRIFT spectroscopy. Holz als Roh-Werkstoff 61(2):216-220.

Wikberg, H.; Maunu, S.L. 2004. Characterization of thermally modified hard- and softwoods by ${ }^{13 C}$ CPMAS NMR. Carbohydrate Polymers 58:461-466. 
Yalcin, M.; Sahin, H.I. 2015. Changes in the chemical structure and decay resistance of heattreated narrow-leaved ash wood. Maderas-Cienc Tecnol 17(2):435-446.

Yamamoto, K.; Simatupang, M.H.; Hashim, R. 1998. Caoutchouc in teak wood (Tectona grandis): Formation, location, influence on sunlight irradiation, hydrophobicity and decay resistance. Holz als Roh- und Werkstoff 56(3):201-20. 